\title{
PENDIDIKAN ISLAM DAN TANTANGAN MODERNITAS (Input, Proses dan Output Pendidikan di Madrasah)
}

\author{
Muhammad Anas Ma`arif \\ Dosen Institut Pesantren KH Abdul Chalim Mojokerto \\ anasdt16@gmail.com
}

\begin{abstract}
Discussing education is never finished, there is always something new in the world of education. Education today has the challenge of modernity that makes education must innovate even more Islamic education. Education is not just looking for input is good for the process be graduates (output) is good but how a quality process that makes the product (graduates) were good. Therefore, to answer the challenges of modernity, education must have a strategy to develop education as an input, education as a process and education as a superior product.
\end{abstract}

Keywords: Islamic Education, input, output, Proces, and Modernity

\section{A. PENDAHULUAN}

Berbicara pendidikan memang tidak pernah ada batas dan ujung, selalu menarik untuk di bahas dan dikaji sekaligus dikembangkan. Pendidikan Islam mempunyai sejarah yang sangat panjang dalam pengertian yang seluas-luasnya, pendidikan Islam semakin berkembang seiring dengan kemunculan dan berkembangnya Islam itu sendiri.

Pendidikan merupakan suatu proses penyiapan generasi muda untuk menyiapkan kehidupan dan memenuhi tujuan hidupnya secara efektif dan efesien ${ }^{1}$. Sedangkan pendidikan Islam adalah, suatu pendidikan yang melatih perasaan murid-murid dengan cara begiru rupa sehingga dalam sikap hidup, tindakan, keputusan, dan pendekatan mereka terhadap segala jenis pengetahuan, mereka di pengaruhi sekali oleh nilai spiritual dan sangat sadar akan nilai etis Islam ${ }^{2}$.

Meskipun pendidikan mempunyai banyak intrepetasi definisi baik dari tarbiyah, ta lim dan ta`dib akan tetapi dilihat dari tujuan pendidikan Islam pasti akan sama yaitu,

1 Azyumardi Azra and Idris Thaha, Pendidikan Islam: Tradisi Dan Modernisasi Di Tengah Tantangan Milenium III, Cet. 1 (Jakarta: Kencana kerja sama dengan UIN Jakarta Press, 2012), Pengantar.

${ }^{2}$ Hujair AH Sanaky, "Studi Pemikiran Pendidikan Islam Modern," Jurnal Pendidikan Islam, Konsep Dan, 1999. manusia yang berahklak mulia ${ }^{3}$ Atau membentuk pribadi khalifah bagi anak didik yang memiliki fitrah, roh disamping badan, kemauan yang bebas dan akal, dengan kata lain, pendidikan adalah mengembangkan ke empat aspek tersebut sehingga menempati kedudukan khalifah ${ }^{4}$.

Pendidikan Islam juga memiliki pekerjan yang berat yaitu terhadapa tantangan modernitas. Modernisasi sendiri yang mulai digulirkan di Eropa Barat pada kurun waktu 500 yang lalu segera menjadi isu global sehingga seluruh wilayah pada akhirnya dapak dari kebudayaan barat yang dinamis, bahkan masyarakat yang dikategorikan statis sekalipun mendapai imbas dari arus modernisasi tersebut ${ }^{5}$.

Modernitas merupakan sebuah konsep, kondisi, dan gerakan yang mampu menampung beragam tanda, cita-cita, impian, harapan, permasalahan, pergeseran, perubahan, kekecewaan, penaklukan, dan halhal lain yang terkesan sederhana namun rumit bagi sekelompok orang.

\footnotetext{
${ }^{3}$ Fajar Malik, Holistika Peikiran Pendidikan, 1 (Jakarta: Raja Grafindo Persada, 2005), 64.

4 Uno Hamzah B, Profesi Kependidikan, Problema, Solusi Dan Reformasi Di Indonesia, 7 (Jakarta: Bumi Aksara, 2011), 67.

5 Muhammad Ihsan, "Pendidikan Islam Dan Modernitas Di Timur Tengah: Studi Kasus Mesir," Hunafa: Jurnal Studia Islamika 4, no. 2 (2007): 130.
} 
Modernitas ini tidak mengikuti salah satu jalan tunggal. Kehidupan modern adalah sebuah "dunia yang tidak terkendali" (runaway world) dengan langkah, cakupan dan kedalaman perubahan yang lebih besar di bandingkan dengan system sebelumnya ${ }^{6}$.

Karena tantanangan modernitas yang sangat significant pada pendidikan di haruskan modernitas yang mempengaruhi kehidupan manusia bisa di selesaikan pada ranah pendidikan. Karena modernitas sendiri bisa menjadikan identitas diri tidak jelas seperti apa yang dikatakan oleh Giddens.

Modernisasi sendiri ditandai oleh kreatifitas manusia dalam mengatasi kesulitan hidupnya di dunia. Fazlur Rahman yang dikutip oleh Sunarto mendefinisikan modernisasi dengan usaha-usaha untuk melakukan harmonisasi antara agama dan pengaruh modernisasi yang berlangsung di dunia Islam ${ }^{7}$. Modernitas di pengaruhi beberapa masalah seperti ekonomi, budaya konsumeris dan rasionalitas formal.

Dari permasalah beberapa teori tentang modernitas seperti menurut Marx modernitas ditentukan oleh ekonomi kapitalis. Diharapkan pendidikan bisa mengembangkan dan menjawab tantangan modernitas yang baik dari segi input pendidikan seperti, input peserta didik, input tenaga kependidikan dan input sarana prasarana. Proses pendidikan yang lebih humanis, lebih kreatif dan inovatif dan menjadikan output peserta didik bisa menjawab tantangan modernitas tersebut.

Oleh sebab itu pendidikan dewasi ini bisa menjadi obat mujarab untuk harmonisasi agama dan pengaruh modernisasi. Pendidikan bukan hanya mengedepankan intelektual semata akan tetapi bisa memainkan peran qolb, aqal, nafs dan jism. Dan yang bisa mengembangkan potensi manusia tersebut hanyalah pendidikan Islam.

Dari permasalahan di atas tantangan yang di hadapi madrasah adalah integrasi antara pendidikan Islam dan sains. Khudori Sholeh, menyatakan bahwa sebenarnya lembaga pendidikan Islam (madrasah) telah melakukan

${ }^{6}$ George Ritzer, Postmodern Social Theory (New York: McGraw-Hill, 1997), 504.

7 A. Sunarto AS, "Paradigma Nahdlatul 'ulama Terhadap Modernisasi," Jurnal Sosiologi Islam 3, no. 2 (2013): 52. integrasi tersebut meskipun dalam pengertian sederhana. Lembaga pendidikan Islam mulai dari Madrasah Ibtidaiyah sampai Perguruan Tinggi, memang telah memberikan materimateri ilmu keagamaan seperti tafsir, hadis, fiqh, dan seterusnya, dan pada waktu yang sama juga memberikan berbagai disiplin ilmu modern yang diadopsi dari Barat. Artinya, mereka telah melakukan integrasi antara ilmu dan agama.

Dari beberapa masalah tersebut maka pendidikan Islam (madrasah) harus bisa merencanakan, mengatur, mengaplikasikan dan mengembangkan potensi peserta didik baik dari cara penerimaan siswa (in-put), proses pembelajaran dan out-put peserta didik. Dengan demikian maka penulis akan mencoba untuk mengupas permasalahan tersebut

\section{B. HASIL DAN PEMBAHASAN In-Put Siswa di Madrasah}

Madrasah adalah bahasa arab dalam bahasa Indonesia berarti tempat belajar, atau sekolah kalau dalam bahasa lain bisa disebut school $^{8}$. Madrasah Menurut Muhaimin yaitu tempat untuk mencerdaskan peserta didik, menghilangkan ketidaktahuan, atau memberantas kebodohan mereka, serta melatih keterampilan mereka sesuai dengan bakat, minat dan kemampuanya. Pengetahuan dan keterampilan seseorang akan cepat using sekaras dengan kemajuan ipteks dan perkembangan zaman, sehingga madrasah pada dasarnya sebagai wahana untuk mengembangkan kepekaan intelektual dan informasi, serta memperbaharui pegetahuan, sikap dan keterampilan secara berkelanjutan agar tetap up to date dan tidak cepat usang ${ }^{9}$.

Menurut Arief Furchan yang di kutip oleh Bakar bahwa madrasah sampai saat ini yang jumlahnya ribuan di Indonesia, masih tetap menjadi tumpuan harapan umat Islam yang mengininkan anak-anaknya menguasai ilmu dunia dan ilmu akhirat sekaligus yang belum tentu bisa diberikan oleh sekolah umum. Namun kenyataanya, madrasah kalah

${ }^{8}$ Idi Abdullah and Safarina, Etika Pendidikan, Keluarga, Sekolah Dan Masyarakat, Cet. 2 (Jakarta: PT Raja Grafindo, 2015), 161.

9 Muhaimin, Pengembangan Kurikulum Pendidikan Agama Islam, Cet. 5 (Jakarta: Raja Grafindo Persada, 2012), 183-84. 
Nidhomul Haq Vol 1 No: 2 Juli 2016

ISSN 2503-1481

bersaing dalam kualitas pendidikan dengan sekolah umum. Banyak faktor yang menyebabkan madrasah tertinggal dengan sekolah umum ${ }^{10}$.

Kekalahan tersebut memang ada benarnya akan tetapi, madrasah dengan berbagai keterbatasan tetap mampu untuk survive dalam melaksanakan pendidikan di Indonesia walaupun madrasah kurang dapat perhatian dari pemerintah.

Pendidikan Islam (madrasah) pada saat selalu berbenah bahkah di bilang mandiri dan survive walaupun tanpa uluran bantuan dari pemerintah. Lembaga yang mandiri dan sanggup bersaing untuk menjawab problematika masyarakat sehingga madrasah sendiri sudah menerapkan konsep pendidikan berbasis masyrakat community based education. ${ }^{11}$

Dari segi yang lain pencapain pendidikan madrasah (MI, MTs, MA) dalam empat dasawarsa terakir sangat fenomenal. Pencapaian utama dari segi hukum adalah pengakuan Negara melalui UU Sisdiknas No. 2/1989 dan UU sisdiknas No. 20/2003. Dengan UU ini madrasah tidak lagi marjinal dan asing dari pendidikan nasional secara keseluruhan. Seperti disampaikan Azra dalam "reform in Islamic Education: a Global Prespective seen from Indonesian case" (Cambrigde University, UK 9-10 April 2011) sebaliknya madrasah mengalami mainstreaming pengarusutamaan yang membawa madrasah ke dalam tranformasi dan pembaharuan yang sangat fenomenal ${ }^{12}$.

Madrasah merupakan pendidikan yang inklusif yaitu menerima semua peserta didik tanpa ada klasifikasi dan diskriminasi sehingga madrasah sendiri sering disebut bengkel atau disebut juga rumah sakit (analogi orang sakit yaitu madrasah ibarat dokter yang menerima semua pasien di rumah sakit) yaitu menerima peserta didik yang tidak masuk kualifikasi di sekolah negeri dengan berbagai aturan masuk lembaga tersebut.

10 Abu Bakar, "Sejarah Transformasi Pendidikan Islam Di Indonesia Menurut Arief Furchan," Tasamuh 7, no. 1 (2016): 8.

${ }^{11}$ Muhaimin, Pengembangan Kurikulum, 184.

${ }^{12}$ Azra and Thaha, Pendidikan Islam, 98.
Input pendidikan adalah segala sesuatu yang harus ada dan tersedia karena dibutuhkan untuk berlangsungnya suatu proses. Segala sesuatu yang dimaksud adalah berupa sumberdaya, perangkat-perangkat lunak serta harapan-harapan sebagai alat dan pemandu bagi berlangsungnya proses. Sedangkan menurut Ahmad Jamin, input adalah (masukan) yaitu siswa/mahasiswa yang akan diproses menjadi tamatan (output $)^{13}$.

Dalam system pendidikan peserta didik merupakan komponen input yang harus dikelola secara efektif dan efisien agar menjadi output yang berkualitas. Sebagai input pendidikan peserta didik sesungguhnya merupakan subyek yang harus melakukan proses pembelajaran. Istilah siswa atau murid sering juga disebut peserta didik yang mana pada hakikatnya memerlukan bantuan orang dewasa untuk tumbuh dan berkembang sesuai dengan potensinya. Menurut Undang-undang system pendidikan nasional bahwa peserta didik adalah anggota masyarakat yang berusaha mengembangkan potensi diri. Melalui proses pembelajaran yang tersedia pada jalur, jenjang dan jenis pendidikan tertentu.

Membahas tentang peserta didik pada dasarnya membahasa tentang hakikat manusia, karena sesungguhnya peserta didik adalah manusia, untuk itu kajian tentang peserta didik tidak lepas dari pembahasan tentang hakikat manusia. Hakikat manusia secara teologis adalah mahluk yang diciptakan oleh Alloh sebagai hambanya untuk mengelolah bumi (khalifah fil ardhi).

Manusia sendiri secara fitrah cenderung melakukan kejahatan oleh sebab itu pendidikan diperlukan untuk membentuk fitrah tersebut menjadi pribadi yang baik ${ }^{14}$.

Input sendiri jika dilihat dari realita yang ada bagaimana pandangan sekolah/madrasah terhadap penerimaan siswa baru. Bagaimana dengan kondisi anak didik dalam kaitanya

13 Ahmad Jamin, "Pendidikan Islam Sebagai Sebuah Sistem (transformasi Input Menuju Output Yang Berkarakter)," Islamika 15, no. 2 (August 18, 2016): 181.

14 Abu Muhammad Iqbal, Pemikiran Pendidikan Islam: Gagasan-Gagasan Besar Para Ilmuwan Muslim, Cetakan 1 (Yogyakarta: Pustaka Pelajar, 2015), 51. 
Nidhomul Haq Vol 1 No: 2 Juli 2016

ISSN 2503-1481

dengan hak mereka untuk dapat bersekolah dan menerima pendidikan. Pola umum madrasah/sekolah di Indonesia yang membuka pendaftaran sebanyak-banyaknya, kemudian mengdakan test seleksi. Misalnya, 350 pendaftar, yang diterima hanya 100 peserta didik, siapakah 100 peserta didik tersebut? Pastinya mereka adalah yang menduduki peringkat 1 sanpa dengan 100 dari calon peserta didik yang 350 . Lalu bagaiaman dengan peserta didik yang 250 tersebut ${ }^{15}$. Inilah seharunya menjadi perhatian para para pakar pendidik.

Masalah input ini juga mendapat kritikan oleh Eni Purwati yaitu tidak sepenuhnya lembaga baik sekolah atau madrasah bisa menerima peserta didik dengan keterbatasan fisik (ABK), dan juga bagi anak-anak yang diterima disebuah sekolah/madrasah, kemudian dikelompok-kelompokan menjadi beberapa rombongan belajar sesuai dengan kapasitas ruangan kelas yang tersedia. Namun, masih banyak lembaga-lembaga yang membagi kelas mereka dengan kemampuan kognitifnya, umumnya untuk kelas A ditempai anak yang pintar dan kelas B untuk kemampuan dibawahnya dan seterusnya ${ }^{16}$.

Secara psikologi hal tersebut menjadikan peserta didik kerap menimbulkan masalah, yaitu masalah integrasi sosial dikelas kurang terjamin atau taraf-taraf prestasi belajar yang tidak jelas-jelas akan lebih lebih baik ${ }^{17}$ jika kondisi tersebut benar-benar di awasi oleh pendidikan yang lebih professional.

Dari beberapa hal tersebut secara otomatis telah melabeli anak-anak dengan label pintar dan bodoh. Sedangkan pendidikan sendiri adalah bertujuan untuk mendidik anak tersebut tanpa melihat golongan, ras, fisik dan agama. Anak-anak tidak bisa disebut bodoh, akan tetapi belum mendapatkan guru yang tepat bagi dirinya.

Perlu diperhatikan untuk pengelolaan input pendidikan berbasis multiple Intelligensia: (a) system rekrutmen siswa baru tanpa test, jumlah siswa baru dibatasi jumlah

15 Eni Purwati, "Pendidikan Islam Berbasis Multiple Inteligences System (mis)," Uin Surabaya, 2011, 14.

${ }^{16}$ Ibid., 15.

17 Santrock John W, Psikologi Pendidikan, 2nd ed., 6 (Jakarta: Prenada Media Grup, 2015), 326. daya tamping kelas yang disediakan (b) peserta didik yang diterima di madrasah tidak hanya anak normal saja, akan tetapi juga menerima anak berkebutuan kusus (ABK). (c) setiap tahun diadakan tes Multiple Intelligeces Reseach (MIR) untuk semua siswa yang bertujuan untuk pengelompokan rombongan belajar sesuai kecerdasan dan kondisi siswa, dilaksanakan rekrutmen guru berkualitas dan syarat utama berkomitmen. (d) mengubah kondisi siswa dari negative ke positif denan berbagai kecerdasan siswa yang lebih dominan $^{18}$.

Dengan demikian jika input siswa diseleksi secara intelektual (benih-benih bagus) maka seharusnya dengan bekal tersebut, bisa menghasilkan output yang istimewa. Akan tetapi jika input peseta didik tidak diseleksi, dan seharusnya diproses dengan metode yang bagus sehingga menjadikan output peserta didik bernilai bagus (good).

Untuk menunjang tercapai suatu input pendidikan tidak hanya pada peserta didik saja akan tetapi input pada guru yang berkualitas dan standar (bukan asal menerima), input visi misi, input tujuan pendidikan yang lebih progressive. Hasil kesuksesan akedemik peserta didik bisa di bilang sukses apabila di pengaruhi oleh kualitas pengajaran yang diberikan kepada peserta didik (seperti kelas regular tanpa diskriminasi, ruang sumber daya atau kelas pendidikan kusus) harus dilakukan inklusi tersebut dan akan bekerja lebih baik jika guru kelas regular dan kusus diberikan pelatihan yang panjang dan baik, merencanakan waktu, dukungan administrative, dan terkadang staf pengajar tambahan ${ }^{19}$.

Input pendidikan yang lebih penting lagi adalah seleksi untuk seorang pendidik yang benar-benar kompeten pada kemampuan mendidiknya. Madrasah mengalami kendala pada seleksi masuk guru. Kebanyakan di madrasah hanya memberdayakan orang yang lulusan kurang kompeten dan pendidik yang sudah berusia senja. Oleh sebab itu madrasah perlu modernisasi pendidikan di bidang seleksi calon guru yang baik untuk peserta

18 Purwati, "Pendidikan Islam Berbasis Multiple Inteligences System (mis)," 24.

${ }^{19}$ John W, Psikologi Pendidikan, 242. 
ISSN 2503-1481

didik. Karena pendidik adalah faktor penting dalam pendidikan maka seharusnya di adakan kualifikasi masuk calon guru. Karena kualitas lulusan madrasah banyak dipengaruhi oleh kualitas guru-gurunya ${ }^{20}$.

Dan rendahnya kualitas guru karena beberapa hal berikut: (1). Adanya mismatch, guru tidak sesuai ngajar pada bidangnya. (2). Kulitas calon guru, profesi guru kurang menarik pada generasi muda. Karena memang perhargaan yang sangat rendah. (3). Lulusan yang belum memenuhi kualifikasi sebagai guru madrasah ${ }^{21}$.

Karena peran guru itu sama dengan tugas Nabi "Ulama' itu dalah pewaris Nabi" oleh sebab itu guru harus benar-benar mampu menjadi guru professional. Adapaun cirri-ciri guru professional adalah sebagai berikut: (1) mempunyai komitmen pada proses pembelajaran (2) menguasai secara mendalam materi pelajaran dan mengajarkanya (3) mampu berpikir sistematis tentang apa yang dilakukanya dan belajar dari pengalamanya; dan (4) merupakan bagian dari masyarakat belajar dalam lingkungan profesinya yang memungkinkan mereka untuk selalu meningkatkan keprofesionalismenya ${ }^{22}$.

Harapan orang tua pada anaknya adalah memahami islam secara menyeluruh dengan pengetahuan sains yang mumpuni. Oleh sebab itu madrasah mempunyai peluang besar dalam hal ini sebab, madrasah telah mengintegrasikan pendidikan Islam dan sains. Hanya saja kelemanya adalah sumber daya manusia di madrasah belum pada level tersebut.

Input yang tidak kalah penting adalah strategi dan manajemen pendidikan yang mengarah pada menjawab kebutuhan masyarakat saat ini. Sehingga dengan hal tersebut madrasah selalu terbuka untuk masukan yang mendidik bagi lembaga tersebut.

Input dari masyarakat kedalam sistem pendidikan yang di kemukakan oleh Azyumardi Azra adalah:

\footnotetext{
${ }^{20}$ Sutrisno and Suyatno, Pendidikan Islam Di Era Peradaban Modern (Jakarta: Kencana, 2015), 135.

${ }^{21}$ Ibid, $52-53$

22 Syaefuddin Saud Udin, Pengembangan Profesi Guru, Cet. 3 (Bandung: Alfabeta, 2013), 97.
}

Ideologis Normatif, menuntut system pendidikan memperluas dan memperkuat wawasan nasional peserta didik. Dikarenakan pendidikan merupakan instrument terpenting dalam pembinaan "nation building".

Mobilisasi politik, kebutuhan bagi modernisasi dan pembangunan menuntut system pendidikan mendidik, mempersiapkan, dan menghasilkan kepemimpinan modernitas dan innovator yang dapat memelihara pembangunan nasional.

Mobilisasi ekonomi, kabutuhan pada tenaga kerja yang handal menuntut system pendidikan mempersiapkan peserta didik menjadi sumber daya manusia yang unggul dan mampu mengisi berbagai lapangan pekerjaan.

Mobilisasi sosial, peningkatan harapan bagi mobolitas sosial dalam modernisasi menuntut pendidikan memberikan akses dan venueke arah tersebut.

Mobilisasi cultural, modernisasi menimbulkan perubahan cultural menuntut system pendidikan mampu memelihara stabilitas dan mengembangkan warisan cultural yang kondusif bagi pembangunan ${ }^{23}$.

Modernisasi pendidikan islam terutama di marasah tidak semua harus di modernkan dalam memenuhi kebutuhan tersebut. Mengikuti maqolah dalam ushul fiqh " al muhafadhotu ala al qodimi as sholih, wal akhdu bi al jadidi al aslah" yaitu memelihara nilai-nilai lama yang baik dan masih relevan pada pendidikan di madarasah dan mengambil nilai-nilai baru yang lebih baik untuk kebutuhan madrasah.

\section{Proses Pembelajaran Siswa di Madrasah}

Pendidikan tidak luput dari beberapa definisi yang telah di jelaskan oleh pakar pendidikan, baik dengan tarbiyah, ta lim dan ta'dib atau bahkah pendidikan yang secara hikmah. Pendidikan yang secara Islami adalah bimbingan yang diberikan kepada seseorang agar berkembang secara maksimal sesuai dengan ajaran Islam ${ }^{24}$.

\footnotetext{
${ }^{23}$ Azra and Thaha, Pendidikan Islam, 32-33.

${ }^{24}$ Malik, Holistika Peikiran Pendidikan, 43.
} 
ISSN 2503-1481

Proses pembelajaran adalah di artikan sebagai proses interaksi antara pendidik dan peserta didik untuk mengajak peserta didik agar mau belajar dan terfokus pada peserta didik (student centered) bukan pada pendidik. Atau pembelajaran merupakan perubahan yang bertahan lama dalam perilaku atau dalam kapasitas berperilaku dengan cara tertentu, yang dihasilkan dari praktik dan bentuk-bentuk pengalaman lainya ${ }^{25}$.

Karena sumber utama dalam pembelajaran adalah al-Quran dan hadist maka dapat dipahami ayat berikut: "bacalah dengan menyebut nama Tuhanmu yang menciptakan. Dia telah menciptakan manusia dari segumpal darah" (al-Alaq-1-3)

Proses belajar mengajar berlangsung dari Tuhan kepada Nabi Muhammad SAW, melalui metode membaca. Dengan perantara malaikat jibril. Tuhan ingin agar Nabi SAW membacakan segala sesuatu yang disampaikan oleh malaikat jibril. Para ulama tafsir melihat bahwa kata kerja fiil amar yakni kata iqra (bacalah) pada ayat pertama tidak ada maf ulnya (objeknya) hal ini menunjukan bahwa yang dibaca ini menunjukan beberapa hal yang amat luas. Yakni tidak hanya membaca yang tersurat atau tertulis akan tetapi membaca yang tersirat/tidak tertulis ${ }^{26}$. Dalam artian lain membaca juga termasuk mengamati, mengobservasi, meneliti dan mengumpulkan informasi.

Pendidikan di madrasah tidak akan berjalan jika tidak memiliki system dalam pendidikan dan system tersebut memiliki beberapa komponen sebagai berikut. (1) dasar dan tujuan pendidikan, landasan digalinya nilai-nilai penddikan (2). Input, peserta didik, guru, dan sarana prasarana yang diproses untuk menjadi tamatan (output/produk). (3) Pendidik dan Tenaga Kependidikan, kurikulum, administrasi, sarana yang termasuk standar pendidikan yang di atur pemerintah tahun 2003 (sumber daya pendidikan). (4)Manusia, orang tua dan

25 Dale H. Schunk, Learning Theories: An Educational Perspective, 6th ed (Boston: Pearson, 2012), 5.

${ }^{26}$ Udin, Pengembangan Profesi Guru, 141. masyarakat, kondisi alam, sosial, budaya, politik, ekonomi ${ }^{27}$.

Dibandingkan dengan pendidikan di sekolah umum, madrasah mempunyai misi yang mulia. Ia bukan saja memberikan pendidikan umum (seperti halnya sekolah umum) tetapi memberikan pendidikan agama $^{28}$ yang secara komprehensif dengan mengintegrasikan pendidikan agama dan sains baik secara materi maupun kurikulumnya.

Pendidikan yang baik tidak hanya mengambil input yang baik akan tetapi proses yang baik juga harus diperhatikan. Sehingga pendidikan tersebut bisa menjadikan produk yang baik, karena pendidikan itu tidak hanya sebagai proses akan tetapi pendidikan juga sebagai produk.

Pembelajaran (instructional) adalah guru tidak hanya sebagai satu-satunya narasumber dan pengajar akan tetapi juga sebagai fasilitator yang membantu peserta didik belajar. Proses pembelajaran adalah proses komunikasi guru yang berperan sebagai komunikator/pengirim pesan ${ }^{29}$. Tugas sebagai komunikator adalah mengolah pesan sehingga menjadi menarik untuk diterima dan di eksplorasi oleh peserta didik. Pembelajaran ini berbeda dengan pengajaran (teaching) dan belajar (learning). Oleh sebab itu pembelajaran adalah proses aktivitas yang berkesinambungan dan terdapat tahanpantahan yang sistematis dan terarah ${ }^{30}$.

Proses pembelajaran sendiri memiliki komponen utama sehingga dalam pembelajaran tersebut menjadi semakin optimal. Komponen tersebut adalah guru/pendidik, tujuan pembelajaran, strategi pembelajaran, materi/isi, evaluasi, komponen

27 Jamin, "Pendidikan Islam Sebagai Sebuah Sistem (transformasi Input Menuju Output Yang Berkarakter)," 182.

28 Arief Furchan, Transformasi Pendidikan Islam Di Indonesia: Anatomi Keberadaan Madrasah Dan PTAI (Yogyakarta: Gama Media, 2004), 43.

${ }^{29}$ A. Rusdiana, Konsep Inovasi Pembelajaran

(Bandung: Pustaka Setia, 2014), 40.

${ }^{30}$ Surya Mohammad, Psikologi Guru, Konsep Dan Aplikasi, Dari Guru Untuk Guru, (Bandung: Alfabeta, 2013), 113. 
ISSN 2503-1481

tersebut harus berorientasi pada pencapaian tujuan pendidikan Islam ${ }^{31}$.

Sedangkan W.S Winkel menyebutkan bahwa komponen-komponen pembelajaran adalah Prosesdur didaktis (kegiatan tenaga pengajar), Media pengajaran, dan pengelompokan peserta didik sesuai dengan kecerdasannya masing-masing ${ }^{32}$. Akan tetapi yang akan dijelaskan berikut adalah komponen-komponen yang disebutkan oleh Jamin dalam penelitianya.

Tujuan pembelajaran dewasa ini harus mencakup tujuan Pendidikan Nasional, tujuan Institusional, tujuan kurikuler dan tujuan Instruksional. Tujuan pembelajaran pada peserta didik harus relevan dengan kebutuah peserta didik sekaligus sejalan dengan pendidikan Islam yang temuat dalam alQuran dan Hadist.

Materi/isi bisa disebut dengan kurikulum, dalam pembelajaran kurikulum ini menentukan tercapainya suatu proses pembelajaran. Komponen kurikulum sendiri sudah ditentukan oleh pemerintah, akan tetapi untuk di lembaga madrasah lebih variatif dan berkarakter dengan corak Islami sehingga di harapkan kurikulum ini memuat materi yang bisa menjadikan peserta didik menjadi pribadi yang baik, sholeh dan berintelektual yang tinggi.

Kurikulum dewasa ini juga harus dikembangkan dan persoalan tersebut harus diperhatikan adalah (1). Pentingnya mata pelajaran yang dipilih (2). Pentingnya proses (3) bahan Mengajar, (4). Kebutuhan penyeleksian secara rasional (4) Keberadaan pengetahuan anak didik.

Komponen yang lain adalah strategi pembelajaran, dalam proses pembelajaran seorang pendidik perlu memahami suatu strategi. Strategi menunjuk pada suatu pendekatan (approach), metode (method) dan peralatan pembelajaran yang diperlukan. Strategi lebih lanjut bisa diseut dengan cara yang dimiliki seorang pendidik untuk dalam proses belajar mengajar. Dengan menggunakan strategi yang tepat, diharapkan

31 Jamin, "Pendidikan Islam Sebagai Sebuah Sistem (transformasi Input Menuju Output Yang Berkarakter)," 182.

32 W.S Winkel, Psikologi Pengajaran, 10th ed. (Yogyakarta: Media Abadi, 2009), 304. hasil yang diperoleh dalam pembelajaran memuaskan baik dari pendidik, peserta didik, masyarakat dan yang ada dalam pendidikan ${ }^{33}$.

Metode yang dipakai untuk proses pembelajaran di madrasah seharusnya lebih variatif untuk menjaga motivasi dan minat belajar peserta didik tetap bagus dan semangat. Metode yang di pakai guru dalam pembelajaran yang lebih kreativ dan inovatif akan menunjukan: (1) komitmen, (2) pengetahuan tentang pokok bahasan; (3) pengetahuan tentang tehnik dan skill (4) keterlibatan dengan tugas ${ }^{34}$

Evaluasi pembelajaran juga sangat diperlukan dalam menentukan proses pembelajaran berjalan dengan maksimal. Mengingat komponen evaluasi berhubungan erat dengan komponen lainya, maka cara penilaian evaluasi ini akan menentukan tujuan pembelajaran, materi dan bahan, serta proses pembelajaran.evaluasi ini harus dilakukan terus menerus bukan hanya sebatas member nilai untuk menentukan grade. ${ }^{35}$

Agar evaluasi pembelajaran di madrasah dapat optimal, akuran dan bermanfaat bagi peserta didik dan masyarakat, maka evaluai dalam pembelajaran harus menerapkan beberapa prinsip umum sebagai berikut: (1) valid, (2) berorientasi pada kompetensi (3), berkelanjutan (4) menyeluruh, (5) bermakna (6), adil dan obyektif (7) terbuka (8) iklas (9) praktis (10) di catat dan akurat ${ }^{36}$.

Dari semua komponen tersebut yang paling diperhatikan adalah aktor dalam pembelajaran yaitu pendidik yang memiliki peran penting dalam membentuk peserta didik, dan peran pendidik sendiri tidak hanya mengajar tetapi membimbing, mengarahkan dan memfasilitasi.dan sumber daya manusia pertama yang harus dibenahi adalah pendidik. Pembenahan yang dimaksud bisa saja sector

33 Abdullah Idi, Pengembangan kurikulum: teori dan praktik, 2nd ed. (Jakarta: Raja Grafindo Persada, 2016), 38.

${ }^{34}$ Florence Beetlestone, Creative Children, Imaginative Teaching (Buckingham; Philadelphia: Open University Press, 1998), 9.

${ }^{35}$ John W, Psikologi Pendidikan, 637.

36 Ramayulis, Ptofesi dan Etika Keguruan (Jakarta: Kalam Mulia, 2013), 295-97. 
ISSN 2503-1481

penguatan akademik, penguatan ekonomi, dan penguatan inspirerend. ${ }^{37}$

Adapun fungsi pendidik adalah (1). Sebagai contoh (uswatun hasanan untuk peserta didik (2). Sebagai pendidik (3). Sebagai pengajar dan pembimbing (4). Sebagai pelajar maupun administrator pendidikan.

Dalam praktiknya menjadi guru tidak semudah yang di bayangkan berikut adalah proses perkembangan karir guru yang ditempuh dalam perjalanan waktu sekurangkurangnya ada lima tahapan yaitu: (1) masa penanaman nilai keguruan, (1) mulai terjun berhidmad sebagai guru (3) selalu tetap berada dalam dunia guru (4) beraktifitas di luar tembok kelas dengan tetap berada dalam koridor guru (5) meneliti situs-situs jenjang karir guru ${ }^{38}$.

Dan syarat menjadi pendidik menurut Hamzah B. Uno adalah, Harus berijasah, harus sehat jasmani dan rohani, harus bertakwa kepada Tuhan Yang maha Esa, harus bertanggung jawab, harus berjiwa nasional $^{39}$. Syarat tersebut adalah syarat yang secara umum dan harus dimilik oleh pendidik.

Pendidik juga harus bisa mengembangkan potensi peserta didik sesuai dengan kecerdasanya. Oleh sebab itu pendidikan juga harus menguasai isi/materi pembelajaran, strategi dalam menggunakan metode dan pendekatan pembelajaran, serta evaluasi pembelajaran. Sehingga tujuan pembelajaran bisa tercapai.

Pembelajaran di madrasah selama ini terkenal konservatif (kuno) oleh sebab itu banyak hal yang harus dibenahi dalam mengembangkan proses pembelajaran. Terlebih lagi dalam strategi pembelajaran madrasah masih terkenal memakai pembelajaran hanya satu arah yaitu dengan metode caramah dan dengan pendekatan yang kurang bervariasi.

37 Samsuddin Samsuddin, "Format Baru Transformasi Pendidikan Islam," Islamica: Jurnal Studi Keislaman 7, no. 1 (January 23, 2014): 172, doi:10.15642/islamica.2012.7.1.161-185.

${ }^{38}$ Mohammad, Psikologi Guru, 225.

39 Hamzah B, Profesi Kependidikan, Problema, Solusi Dan Reformasi Di Indonesia, 29.
Proses pembelajaran yang baik menurut Purwanti dalam pendidikan berbasis multiple intelligences adalah sebagai berikut:

1) Penyusunan lesson plan berdasarkan hasil MIR dan SOP konsultasi lesson plan, dengan memperhatikan 8 kecerdasan tertinggi, gaya belajar dan kondisi siswa.

2) Penggunaan strategi multiple intelligences dalam pembelajaran didasarkan pada cara kerja otak secara holistic activities dan whole brain dengan variasi metode, aktivitas tugas, dan teaching aids yang disesuaikan dengan kondisi kecerdasan siswa.

3) Materi pembelajaran dikaitakan dan di aplikasikan dengan kehidupan sehari-hari untuk menumbuhkembangkan kepedulian lingkungan dan sosial yang berujung pada kecerdasan spiritual menunju Islamic Chracter Building.

4) Waktu kerja guru disekolah/madrasah $50 / 60 \%$ untuk mengajar dan $40 / 50 \%$ untuk menyusun perangkat pembelajaran, konsuktasi dengan guru Agama dan koreksi tugas siswa

5) Madrasah berkerjasama dengan yayasan dan komite memfasilitasi pendidikan dan pelatihan guru secara rutin, minimal 6 kali dalam satu tahun.

6) Menciptakan suasana kondusif dan nyaman dalam pembelajaran, menyediakan shadow teacher dan guru piket sebagai pendamping $\mathrm{ABK}$ dalam proses pembelajaran.

7) Dalam melaksanakan pembelajaran guru dikonsultani oleh seorang konsultan "guardian Angel" yang bertugas membeimbing penyusunan lesson plan, mengobservasi kelas, memberi feedback, dan menilai kompetensi guru ${ }^{40}$.

\section{Out put siswa di Madrasah/sekolah}

Disetiap lembaga pendidikan kebanyakan hanya mementingkan proses dan output akan tetapi melupakan inputnya sehingga

40 Purwati, "Pendidikan Islam Berbasis Multiple Inteligences System (mis)," 25. 
ISSN 2503-1481

pendidikan tersebut terkesan sekuler yaitu tidak berdasarkan nilai-nilai ke Isalam yang mengedepankan humanism pendidikan dan pendidikan yang inklusif.

Masyarakat, dan pihak madrasah bahkan peserta didik menginginkan menjadi output yang sesuai dengan tujuan pembelajaran. Oleh sebab itu kaitanya erat dengan input pendidikan, proses pendidikan dan output pendidikan.

System pendidikan yang bagus adalah memerhatikan aspek sekecil apapun untuk mengembangkan output peserta didik di madrasah/sekolah. Karena pendidikan bukan hanya sebagai proses akan tetapi pendidikan juga sebagai produk. Tamatan output pendidikan Islam yang diharapkan adalah berupa Insan kamil yaitu pribadi yang mengabdi kepada Allah dan menjadi khalifah Allah dimuka bumi (khalifah fi al-Ardhi). ${ }^{41}$

Berikut adalah variable output pendidikan menurut Azyumardi Azra adalah sebagai berikut ${ }^{42}$ :

1) Perubahan sistem nilai: dengan memperluas "peta kognitif" peserta didik, maka pendidikan menanamkan nilai-nilai yang merupakan alternatif bagi sistem nilai tradisional. Perluasan wawasan ini akan merupakan pendorong bagi tumbuh dan berkembangnya "semangat untuk berprestasi" (need of achievement), dan mobilitas sosial. Persoalannya kemudian, sejauh mana sistem dan lembaga pendidikan Islam, khususnya pesantren yang secara sadar mengorientasikan diri pada perluasan "peta kognitif" ini; bahkan sebaliknya terdapat kesan yang kuat bahwa pesantren tetap berkutat pada "normativisme" dan dogmatis lama yang kurang memberikan kesempatan bagi pengembangan kognisi dan kreativitas

41 Jamin, "Pendidikan Islam Sebagai Sebuah Sistem (transformasi Input Menuju Output Yang Berkarakter)," 182.

${ }^{42}$ Imam Mawardi, "Transinternalisasi Budaya Pendidikan Islam: Membangun Nilai Etika Sosial Dalam Pengembangan Masyarakat," HUNAFA: Jurnal Studia Islamika 8, no. 1 (2011): 34-35.
2) Out put politik: kepemimpinan modernitas dan inovator-yang dihasilkan sistem pendidikan dapat diukur dengan perkembangan kuantitas dan kekuatan birokrasi sipil-militer, intelektual dan kaderkader administrasi politik lainnya, yang direkrut dari lembagalembaga pendidikan - terutama pada tingkat menengah dan tinggi

3) Output ekonomi: dapat diukur tingkat ketersediaan SDM atau tenaga kerja yang terlatih dan siap pakai. Dalam pendidikan Islam belum terlambat link and match yang jelas dan kuat antara sistem dan lembaga pendidikan Islam dengan masalah tenaga kerja yang terlatih dan siap pakai tersebut.

4) Out put sosial: dapat dilihat dari tingkat integrasi sosial dan mobilitas peserta didik ke dalam masyarakat secara keseluruhan. Dalam hal ini, integrasi sosial, out put sistem dan lembaga pendidikan Islam kelihatannya relatif berhasil, karena didukung oleh faktor kependudukan Indonesia yang mayoritas muslim. Tetapi dalam hal mobilitas sosial, sistem dan kelembagaan pendidikan Islam kelihatannya belum lagi kelihatan signifikansinya.

5) Out put cultural: tercermin dari upaya-upaya pengembangan kebudayaan ilmiah, rasional, dan inovatif; peningkatan peran integratif, agama; dan pengembangan bahasa pendidikan.

Sedangkan Eni Purwati mengemukakan bahwa seharusnya output pembelajaran bebasis Multiple Inttelligences adalah sebagai berikut ${ }^{43}$ :

1) Penilaian kompetensi siswa, meliputi ranah kognitif (daya pikir/pemahaman materi, psikomotor (produk/karya hasil belajar), dan afektif (sikap respon siswa selama pembelajaran).

2) Siswa yang belum tuntas dalam pembelajaran satu tema, di remidi dan

43 Purwati, "Pendidikan Islam Berbasis Multiple Inteligences System (mis)," 26. 
diberi soal-soal lain sehingga siswa mampu menjawab sesuai dengan apa yang dia bisa.

3) Penilaian kompetensi guru meliputi hal: hasil belajar siswa, kualitas lesson plan, kreativitas, dan perilaku/kinerja. Penilaian tersebut sesuai dengan profesonalisme guru, yaitu kompetensi pedagogik, profesional, kepribadian dan sosial.

4) Setiap semester siswa dan guru menerima rapor. Rapor guru berfungsi sebagai ukuran tingkat profesionalitas dan penentu prestasi yang berkonsekuensi pada kenaikan pangkat dan gaji.

Lulusan akan menjadi lulusan terbaik dan lulusan yang berintegritas tinggi serta berkarakter tidak ditempuh dengan cara mudah tetapi ada beberapa prinsip untuk menjadikan lulusan berprestasi dan berkarakter. (1) Kepemimpinan kepala sekolah yang prefesional. (2). Pendidik/guru yang tangguh dan professional (3). Memiliki tujuan pencapaian filosofis yang jelas (visi, misi). (4). Lingkungan kondusif untuk pembelajaran (5). Jaringan organisasi, networking yang baik. (6). Kurikulum yang jelas serta berkarakter Islam (7). Evaluasi yang baik berdasarkan peta pemahaman sikap, internalisasi nilai, dan pastisipasi peserta didik terhadap problem di sekitarnya. (8) partisipasi aktif orang tua dalam kegiatan sekolah $^{44}$.

Tanpa menghasilkan lulusan yang berkualitas pendidikan di madrasah bukanlah suatu investasi SDM melainkan justru pemborosan baik segi biaya, tenaga maupun waktu. Disamping akan menimbulkan masalah sosial. Lulusan pendidikan dikatakan berkualitas apabila memiliki pengetahuan, keterampilan, dan karakter yang dapat di andalkan dan diakui di tingkat regional, nasional dan internasional. Pendidikan di madrasah yang berorientasi pada lulusan yang berkualitas dan bisa menjawab tantangan modernitas adalah memiliki ciri-ciri sebagai berikut:

44 Misnatun Misnatun, "Pendidikan Pondok Pesantren Dan Tantangan Pasar Bebas (Sebuah Antologi Dialektika-Progresif Pondok Pesantren Dan Perubahan Zaman)," At Ta'lim: Jurnal Pendidikan 2, no. 2 (2016): 31-49.
1) Keberhasilan pendidikan tidak di ukur dari angka pastisipasi murid tetapi pada tingkat literasi yang dikuasai.

2) Adanya system menejemen/birokrasi pendidikan yang melayani murid dan guru, dan bukan melayani system/birokasi itu sendiri.

3) Madrasah tidak diukur dari menterengnya fasilitas fisik serta proses kulikuler yang dijalankan, melainkan dari kualitas dan kuantitas lulusanya.

4) Standarisasi kualitas lulusan secara nasional aadalah lebih penting dari pada standarisasi kurikulum dan sarananya.

5) Ada kepedulian yang tinggi terhadap kualitas, yang diwujudkan dengan control dan jaminan kualitas (quality control and quality assurance). ${ }^{45}$

\section{KESIMPULAN}

1. Input dalam pendidikan tidak harus peserta didik akan tetapi mencakup pendidik, sarana prasarana dan segala yang bisa di pakai untuk pendidikan, sedangkan input yang baik untuk peserta didik adalah dengan mengadopsi pendidikan inklusif yaitu dengan tidak memilah peserta didik berdasarkan kecerdasan kognitif semata, dan jika mengikuti pendidikan Islam berbasis multiple intelligence adalah dengan mengarahkan peserta didik sesuai kecerdasan yang dominan padanya.

2. Proses pembelajaran yang baik tidak lepas dari beberapa komponen pembelajaran yaitu tujuan pembelajaran, strategi (metode dan pendekatan), evaluasi serta materi pembelajaran akan tetapi semua itu ditunjang dengan kemampuan pendidik yang professional dan sarana prasarana yang memadai.

3. Output pembelajaran ini diharuskan sesuai dengan tujuan pendidikan Islam, menjadikan Insan kamil, manusia khalifah fil ardhi, berkarakter, intelektual yang tinggi, berdedikasi tinggi. Mengamalkan

\footnotetext{
${ }^{45}$ Sutrisno and Suyatno, Pendidikan Islam Di Era Peradaban Modern, 117.
} 
Nidhomul Haq Vol 1 No: 2 Juli 2016

ISSN 2503-1481

semua yang telah di ajarkan dalam pembelajaran. 


\section{DAFTAR PUSTAKA}

A. Rusdiana. Konsep Inovasi Pembelajaran. Bandung: Pustaka Setia, 2014.

Abdullah, Idi, and Safarina. Etika Pendidikan, Keluarga, Sekolah Dan Masyarakat. Cet. 2. Jakarta: PT Raja Grafindo, 2015.

AS, A. Sunarto. "Paradigma Nahdlatul 'ulama Terhadap Modernisasi." Jurnal Sosiologi Islam 3, no. 2 (2013).

Azra, Azyumardi, and Idris Thaha. Pendidikan Islam: Tradisi Dan Modernisasi Di Tengah Tantangan Milenium III. Cet. 1. Jakarta: Kencana kerja sama dengan UIN Jakarta Press, 2012.

Bakar, Abu. "Sejarah Transformasi Pendidikan Islam Di Indonesia Menurut Arief Furchan." Tasamuh 7, no. 1 (2016).

Beetlestone, Florence. Creative Children, Imaginative Teaching. Buckingham; Philadelphia: Open University Press, 1998.

Furchan, Arief. Transformasi Pendidikan Islam Di Indonesia: Anatomi Keberadaan Madrasah Dan PTAI. Yogyakarta: Gama Media, 2004.

Hamzah B, Uno. Profesi Kependidikan, Problema, Solusi Dan Reformasi Di Indonesia. 7. Jakarta: Bumi Aksara, 2011.

Idi, Abdullah. Pengembangan kurikulum: teori dan praktik. 2nd ed. Jakarta: Raja Grafindo Persada, 2016.

Ihsan, Muhammad. "Pendidikan Islam Dan Modernitas Di Timur Tengah: Studi Kasus Mesir." Hunafa: Jurnal Studia Islamika 4, no. 2 (2007): 129-142.

Iqbal, Abu Muhammad. Pemikiran Pendidikan Islam: Gagasan-Gagasan Besar Para Ilmuwan Muslim. Cetakan 1. Yogyakarta: Pustaka Pelajar, 2015.

Jamin, Ahmad. "Pendidikan Islam Sebagai Sebuah Sistem (transformasi Input Menuju Output Yang Berkarakter)." Islamika 15, no. 2 (August 18, 2016).

John W, Santrock. Psikologi Pendidikan. 2nd ed. 6. Jakarta: Prenada Media Grup, 2015.

Malik, Fajar. Holistika Peikiran Pendidikan. 1. Jakarta: Raja Grafindo Persada, 2005.

Mawardi, Imam. "Transinternalisasi Budaya Pendidikan Islam: Membangun Nilai Etika Sosial Dalam Pengembangan Masyarakat." HUNAFA: Jurnal Studia Islamika 8, no. 1 (2011): 27-52.

Misnatun, Misnatun. "Pendidikan Pondok Pesantren Dan Tantangan Pasar Bebas (Sebuah Antologi Dialektika-Progresif Pondok Pesantren Dan Perubahan Zaman)." At Ta'lim: Jurnal Pendidikan 2, no. 2 (2016): 31-49.

Mohammad, Surya. Psikologi Guru, Konsep Dan Aplikasi, Dari Guru Untuk Guru,. Bandung: Alfabeta, 2013.

Muhaimin. Pengembangan Kurikulum Pendidikan Agama Islam. Cet. 5. Jakarta: Raja Grafindo Persada, 2012.

Purwati, Eni. "Pendidikan Islam Berbasis Multiple Inteligences System (mis)." Uin Surabaya, 2011, 41.

Ramayulis. Ptofesi dan Etika Keguruan. Jakarta: Kalam Mulia, 2013.

Ritzer, George. Postmodern Social Theory. New York: McGraw-Hill, 1997.

Samsuddin, Samsuddin. "Format Baru Transformasi Pendidikan Islam." Islamica: Jurnal Studi Keislaman 7, no. 1 (January 23, 2014): 161-85. doi:10.15642/islamica.2012.7.1.161-185.

Sanaky, Hujair AH. "Studi Pemikiran Pendidikan Islam Modern." Jurnal Pendidikan Islam, Konsep Dan, 1999.

Schunk, Dale H. Learning Theories: An Educational Perspective. 6th ed. Boston: Pearson, 2012.

Sutrisno, and Suyatno. Pendidikan Islam Di Era Peradaban Modern. Jakarta: Kencana, 2015.

Udin, Syaefuddin Saud. Pengembangan Profesi Guru. Cet. 3. Bandung: Alfabeta, 2013.

Winkel, W.S. Psikologi Pengajaran. 10th ed. Yogyakarta: Media Abadi, 2009. 